\title{
When Termites' Waste Products Highlight a Fundamental Law of Fertilization under Rainfed Rice Cultivation in West Cote d'Ivoire
}

\author{
Dogniméton Soro, Lacina Yeo, Zoumana Konate, Martinez Arnauth Guei, and Gohi Ferdinand Zro-Bi
}

\section{ABSTRACT}

Food security is a major development issue in Côte d'Ivoire that is experiencing population growth over $3 \%$ per year. Food crop production, however, is experiencing weak growth, most often linked to increase in area. In addition, low yields could be explained by the scarcity of rainfall in a context where farmers hardly use agronomic-based fertilizers without soil analysis although Cote d'Ivoire is agricultural based developing country. To be part of integrated production logic in rice production, a study is initiated in 2016 in Daloa in order to improve the yield of paddy rice by using a local amendment produced by termites kept in captivity on agricultural residues. Four (4) doses of this amendment made of termites' waste products (TWP): $1.8 \% ; 3.6 \%$ and $7.2 \%$ and $14.4 \%$ of one hectare soil weight were tested versus an unfertilized (control) and a NPK fertilized $(100 \mathrm{~kg} . \mathrm{ha})^{-}$. The experimental design consists of randomized complete blocks with three replicates. Plant growth parameters such as plant height at maturity, total number of tillers, number of leaves at the beginning of tillering, biomass at maturity and yield data were collected. The results showed that all agronomic parameters were improved with increasing dose up to an optimum dose that can be found between $7.2 \%$ and $14.4 \%$ of termites' waste products. The highest yield $\left(2484.3 \mathrm{~kg}^{2} \mathrm{ha}^{-1}\right)$ was obtained with the 7.2 $\%$ dose. The results of the application of the TWP on rice showed important yield increases with efficacy varying from 30 to $72 \%$ compared to common fertilizer application and 27.1 to $221.9 \%$ if compared to non-fertilized plot.

Keywords: Amendment, fertilizer, rice, termites, termites' waste product (TWP), valorization, yield.
Published Online: January 18, 2021

ISSN: 2684-1827

DOI: $10.24018 /$ ejfood.2021.3.1.218

\section{Dogniméton Soro*}

University Jean Lorougnon Guede, Laboratoire d'Agrovalorisation, Côte d'Ivoire.

(e-mail: dognysoro@gmail.com)

Lacina Yeo

University Jean Lorougnon Guede, Laboratoire d'Agrovalorisation, Côte d'Ivoire.

(e-mail: tchebelass@yahoo.fr)

Zoumana Konate

University Jean Lorougnon Guede, Laboratoire d'Agrovalorisation, Côte d'Ivoire.

(e-mail: zoumko@yahoo.fr)

Martinez Arnauth Guei

University Jean Lorougnon Guede, Laboratoire d'Agrovalorisation, Côte d'Ivoire.

(e-mail: gueiarnauthmartinez ${ }^{@}$ yahoo.fr) Gohi Ferdinand Zro-Bi

University Jean Lorougnon Guede, Laboratoire d'Agrovalorisation, Côte d'Ivoire.

(e-mail: zraubigof@yahoo.com)

*Corresponding Author

\section{STATEMENT OF NOVELTY}

Soil organisms such as termites and earthworms are recognized as soil engineers who participate in loosening soil and mixing the deep layers constituents with those of the surface. If earthworms are used in the production of high value earthworm compost, termites' activity has always been studied in their environment explaining their social life, contribution to soil and damages to crops. This experience is dealing with another aspect of termite life. The principal aim is to breed termites in semi-controlled environment by valorizing an Ivoirian local practice that consists in collecting termites' by trapping method in poultry rearing. Termites' trapping has never been conducted elsewhere and has not been publish before. It has been conducted to produce TWP and test as soil amendment in rice production.

This paper is presenting a new product (TWP) obtained from termites' trapping that can be used in sustainable management of soil fertility. The results of the application of the TWP on rice showed important yield increases varying from 30 to $72 \%$ compared to common fertilizer application and 27.1 to $221.9 \%$ compared to non-fertilized plot. This organic product has also improved soil texture.

\section{INTRODUCTION}

Rice (Oryza sativa L.) is globally, an important cereal crop widely produced in the world. This cereal is the third mostconsumed grain crop after wheat and maize [1]. About 148.3 million hectares of rice are grown in the world while rainfed rice occupies about 19.1 million hectares equal to $13 \%$ spread over three continents. Asia (10.7 million ha), Latin America (3.7 million ha) and Africa (2.3 million ha) are the greatest producers for rainfed rice [2]. Rice production in Africa accounts represented about $3 \%$ of global production estimated at 720 million tons in 2011 [3]. However, rice needs are growing in sub-Saharan Africa due to population growth of $4 \%$ per year and interest in rice by local people [4]. Its production is facing many biotic and abiotic constraints 
like other countries of the world. Among these, soil fertility management in the hard pedoclimatic and frequent drought periods are the major ones.

Ivorian rice consumption has more than doubled in the last 30 years moving from $30 \mathrm{~kg} /$ capita/year in 1981 to 70 $\mathrm{kg} /$ capita/year now [2]. This change in demand for rice is supported by changes in food habits. Indeed, the country produces only 40 to $45 \%$ of its consumption despite the strong potential of the agricultural sector [5]. This underperformance in rice production leads to food insecurity, malnutrition and poverty [6]. It is possible it be linked to certain production constraints related to scarcity, irregularity and insufficient rainfall. However, parasite pressure, meanly prevalence of blast and leaf blotch, declining soil fertility, varietal potential (low productivity cultivars) and limited access to agricultural inputs (seeds, fertilizer) may also explain this deficiency [7]. Several actions with very promising results have been proposed to fill this production gap and to achieve food self-sufficiency in rice. These include:

- mineral fertilization with chemical fertilizers [8];

- organic fertilization through the use of compost, green manure, nitrogen-fixing legumes [10];

- manure, dung, [11];

- cultivation techniques through the practice of crop combinations, rotations and assolation [12], [13], [9].

However, these different actions have not made it possible to significantly increase rice production in Côte d'Ivoire. The causes mentioned for this failure are the poor popularization of new techniques, the constraints linked to their implementation and above all the financial impact they generate and which cannot be borne by the peasant who practices subsistence agriculture. According to the National Office of Rice Development (ONDR), annual production is $1,399,407$ tons of milled rice for an estimated need of $2,600,000$ tons [14]. The causes mentioned for this failure are the poor distribution of the new techniques, the constraints related to their implementation and especially the financial coast that cannot be supported by the farmers practicing subsistence agriculture.

Rainfed rice production is faced with several constraints such as soil infertility, pests and diseases, drought and global climate changes. Chemical fertilisation as well as varietal improvement have been tested either in crop production or in export products with numerous consequences. In fact, the consequences of chemical fertilisers' application are fertility losses with soil acidification, degradation of soil physical status and loss of soil organic matter [15]. Then, there are environmental pollution and threats on consumer health. It is therefore essential to look for integrated strategies for the sustainability in soil management and crop productivity. Soil organisms such as termites and earthworms are recognized as soil engineers who participate in loosening soil and mixing the deep layers constituents with those of the surface. If earthworms are used in the production of high value earthworm compost, the wildness state of the termites and their extreme mobility makes their captivity living almost impossible despite their strong social structure. Termites' activity is essential in the regeneration and maintenance of soil physical, chemical and biological fertility. Farmers fear termites when drought comes in maize production. But,
Senoufo farmers in the north of Cote d'Ivoire, by combining livestock rearing with tillage, have developed a termite trapping strategy for their poultry. The trapping method is based on the consumption of maize residues by termites in terracotta pots placed all over the bush on potential termite nests. The result of this semi captivity is an organo-mineral product with termites given to poultry. The remaining waste from their feeding area are collected and dumped in the fields as an amendment for soil fertility management. One of the solutions may lie in the use of organic waste products as local fertilizers that are accessible to everyone [16]. This is the soil fertility strategy by which the Senoufo farmer are managing their agricultural plots for generations. It is in this context that this work has been proposed to understand and to explain the termites' waste products (TWP) uses as a soil amendment to the improvement of rice productivity. Specifically, it aimed at evaluating the fertilizing capacity of termites waste products applied to rice cultivation.

\section{EXPERIMENTAL SECTION}

\section{A. Study Area}

The study was carried out at Daloa (Côte d'Ivoire), on the experimental site of Jean Lorougnon Guede University (06 54 '28.9 "north latitude and $06^{\circ} 26^{\prime} 14.8^{\prime \prime}$ west longitude) (Fig. 1). The soils are generally ferralitic, favourable for industrial crops (coffee, cocoa, rubber, etc.) cereal, food, and vegetable crops [17].

The climatic regime is that of the Guinean domain, characterized by an equatorial and subequatorial regime with two rainfall maxima. The month of June represents the peak of the great rainy season and that of September the peak of the short rainy season [18]. The annual rainfall varies between 1,200 and $1,700 \mathrm{~mm}$, the annual average temperature is $25^{\circ} \mathrm{C}$ and the relative humidity of the air is around $75 \%$ [19].

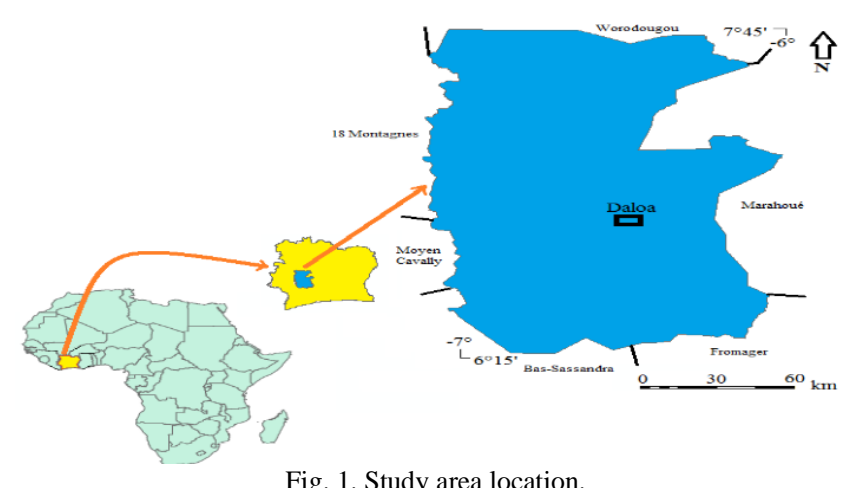

\section{B. Experimental Material}

Seeds of a local rice cultivar named Djoukèmin" of 145 days cycle duration [20] is used. Plants from those seeds constituted the biological material on which growth parameters and yield data are collected.

The technical equipment is composed of ploughing tools, tools for measuring agronomic parameters, tools for studying the soil and equipment for weighing harvests. A camera was 
used for image saving and a GPS Garmin served to save geographical coordinates of the experimental area.

The fertilization material includes was composed of Termites' waste products (TWP) resulting from their activity, NPK fertilizer (15-15-15) at $150 \mathrm{~kg} \cdot \mathrm{ha}^{-1}$ and urea $46 \%$ at $70 \mathrm{~kg} \cdot \mathrm{ha}^{-1}$ in a single broadcast application at the beginning of panicle initiation ( $51^{\text {st }}$ day after sowing).

\section{TWP Production}

A crumbled mass and moistened with agricultural residues is placed in a terracotta pot (canary). This pot is implanted in the living space of termites where clues of their presence are identified by soil veneers on plant and / or animal residues. A shelter is provided to reduce the impact of the sun. Traps are harvested every seven (7) days between 9 a.m. and 11 a.m. in order to minimize the presence of termites in the traps. The harvest is done as follows:

1. Open the trap by turning it over;

2. Empty its contents into a container;

3. Dry the product in the shade;

4. Pass the dry product through a coarse sieve to separate the crude product from the undigested residue;

The harvested TWP is transported to the laboratory and dried in the shade for 24 hours. After drying it is sieved this time with a sieve of $2 \mathrm{~mm}$ mesh then weighed and stored in a labeled plastic bag.

\section{Experimental Design}

The experimental design is a RCBD (Randomized Complete Blocks Design) with three replicates of six (6) fertility levels each (Fig. 2). The applied treatments are:

- T0: (No-fertiliser Check), without amendments;

- T1: Contribution of $1.8 \%$ of the soil mass contained in one ha of control soil corresponding to 36 t.ha $^{-1}$ of Termite Waste Product (TWP).

- T2: Contribution of $3.6 \%$ of the mass of soil contained in one ha of control soil corresponding to 72 t.ha $^{-1}$ of TWP.

- T3: Contribution of 7.2\% of the mass of soil contained in one ha of control soil corresponding to 144 t.ha- ${ }^{-1}$ of TWP

- T4: Contribution of $14.4 \%$ of the soil mass contained in

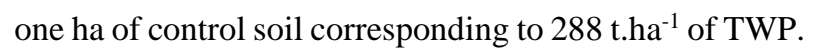

- T5 (Fertiliser Check): 150 kg.ha-1 NPK 151515 at sowing and $70 \mathrm{~kg} \cdot \mathrm{ha}^{-1}$ urea $46 \%$ in a single broadcast application at the beginning of panicle initiation $\left(51^{\text {st }}\right.$ day after sowing) [21].

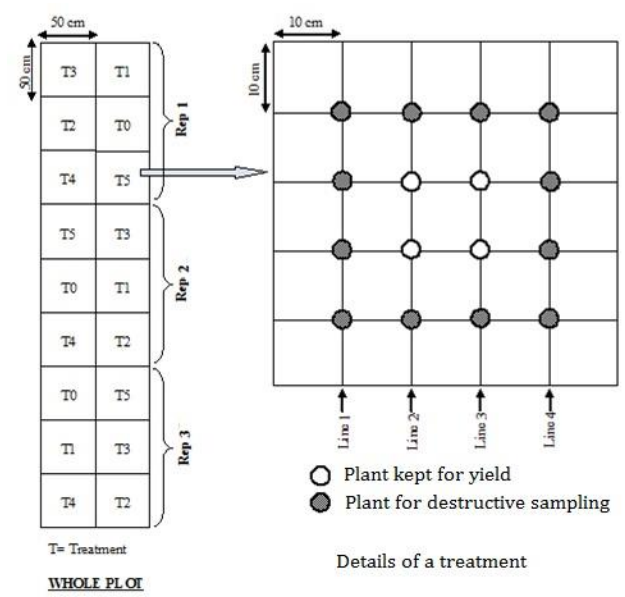

Fig. 2. Experimental design (RBCD).

\section{E. Calculated Values}

The data collected from these six treatments served to draw yield evolution curve as a function of the doses of TWP from which the values of intermediate doses, not included in the test will be deduced. The intermediate doses are defined at $2.5 \%, 4.5 \%, 5.4 \%$ and $6.3 \%$ according to $\mathrm{n}+1.8 \% \mathrm{n}$ being the precedent dose and $1.8 \%$ the increment value.

\section{F. Analysis for Soil and Termites Waste Product}

The control soil sample and a sample of the TWP were analysed at the ESA Soil, Water and Plant Laboratory (Yamoussoukro INPHB). The physicochemical parameters analysed are:

- Soil pH by the potentiometric method using 1: 2.5 soil / water suspension and read using a $\mathrm{pH}$ meter [22].

- Total carbon by Walkey and Black test and potentiometric titration [23]. The organic matter is then determined by calculation according to the formula: \% $\mathrm{MO}=1.724 \times \% \mathrm{C}$

- Total nitrogen by mineralization according to Kjeldhal method [45], then by titrimetry of the ammoniacal nitrogen collected after displacement of the latter by sodium hydroxide and steam entrainment.

- The assimilable phosphorus $\left(\mathrm{P}_{2} \mathrm{O}_{5}\right)$ according to OLSEN method [24]. The extraction is made by sodium hydrogen carbonate at $\mathrm{pH}$ of 8.5 . This method is based on the formation and reduction of a complex of orthophosphoric acid and molybdic acid. The phosphorus content was read using a visible UV spectrophotometer at a wavelength of $825 \mathrm{~nm}$. The result is expressed in ppm.

- Exchangeable potassium $\left(\mathrm{K}_{2} \mathrm{O}\right)$ by extraction with $1 \mathrm{~N}$ $\mathrm{CH}_{3} \mathrm{COONH}_{4}$ ammonium acetate at $\mathrm{pH} 7$ [22].

- Sodium exchangeable by saturation of the soil absorbing complex in favour of a single cation $\left(\mathrm{Na}^{+}\right)$[25].

- Cation exchange capacity by saturation of the soil with calcium ions by a molar solution of calcium chloride followed by washing with 0.01 molar solution of calcium chloride to remove the excess of chloride [26].

\section{G. Measurements on Plant Growth and Productivity}

The height of the seedlings is measured from soil to the end of the longest leaf at the heading. For each replicate, the measurement was repeated on six (6) plants and the average value of the six measurements was considered per treatment.

The number of tillers was determined by the average of tillers per plant calculated on the basis of the number of tillers obtained by counting on six plants at the 139 das.

The number of leaves was determined by calculating the leaves average per plant after counting on six plants per plot at 40 and 139 d.a.s.

Destructive sampling is done on two plants per treat at two different ages at 40 and 139 d.a.s. The plants chosen are gently dug up after abundant watering to preserve all the roots. The roots are then rinsed with water and wrung out with blotting paper. Each fresh plant is weighed before taking the root by section of the stem under the collar. Then, the fresh roots and aerial part of each plant are weighed separately. The plants are then placed in an oven for drying at a temperature of $70^{\circ} \mathrm{C}$. for 48 hours. After drying, the dry mass of each part is determined by weighing. 
The yield was calculated at $15 \%$ moisture by weighing the rice after threshing using the following formula:

$$
\text { Yield }(R)=\frac{\text { Grain mass harvested }(\mathrm{kg})}{\text { Harvested area }\left(\mathrm{m}^{2}\right)} \times \frac{(100-\mathrm{h})}{\mathrm{H}-15}
$$

where: $\mathrm{h}=$ Moisture content of rice at harvest. $\mathrm{H}=$ Moisture content of dried rice.

TWP efficacy was therefore calculated using the following formula:

$$
\operatorname{Efficacy}(\mathrm{E})=\frac{\mathrm{FpY}-\mathrm{CpY}}{\mathrm{CpY}} \times 100
$$

Where: $\mathrm{E}=$ Treatment Efficacy. FpY $=$ Fertilised plot Yield. $\mathrm{CpY}=$ Control plot Yield.

\section{H. Data Analysis}

The data obtained was statistically processed using the SAS version 9.4 software. Analysis of variance (ANOVA) was supplemented by a T-test that ranked the means using the least significant difference (lsd) at the $5 \%$ probability level.

\section{RESULTS AND DisCUSSION}

\section{A. Termite Waste Product Effect on Soil Properties}

The control soil is sandy-loam, very closed to sandy with $76.25 \%$ sand $24.75 \%$ of combined clay and silt constituting the fine fraction of the soil. The termites' activity helped to improve this textural position by raising the combined clay and silt content to $41.23 \%$ with respectively $21.23 \%$ clay and $20 \%$ silt changing the proportion of sand from 76.25 to $58.77 \%$ (Table I). The TWP used to amend the soil was an organo-mineral substance that had improved physical properties compared to the control soil. The granulometry showed an enrichment of the TWP in clay and silt compared to the control soil. Indeed, in their burrowing activities for feeding and building their habitat, termites modify the physical properties of the soil [27] by coming up from the depths, fine elements that they mix with the organic matter produced during the digestion of the residues offered to them. The texture of the TWP is then sandy clay loam while the control soil is sandy loam (Fig. 3). The large amounts of textural and structuring elements available in these substrates could show a double effect of improving water efficiency and mineral dynamics [28]. Their application to the soil will contribute to improve the texture in the soil upper layer. Enrichment in clay and silt suggested better mineral behaviour of the waste products of termites' activity. In fact, the residual product from termite activity showed improved chemical content. The highest level of available phosphorus (83.7 ppm) was obtained in TWP. This product had better cation exchange capacity $\left(13.16 \mathrm{cmol} . \mathrm{kg}^{-1}\right)$ compared to the control soil $\left(9.3 \mathrm{cmol} . \mathrm{kg}^{-1}\right)$. Furthermore, the control soil had more saturated with $\mathrm{Ca}^{2+}(25.6 \%)$ and $\mathrm{Mg}^{2+}(23.7 \%)$ than the TWP $(21.1 \%$ and $16.3 \%$ respectively) which is more loaded with $\mathrm{K}^{+}$with $6.7 \%$ against $1.1 \%$ in the control soil. TWP seemed richer than control with low positive difference for $\mathrm{K}^{+}$(Table I).

The chemical composition of the soils showed that the TWP is richer in phosphorus and had better cation exchange capacity as shown by [29] and [30]. TWP also had high levels of total nitrogen, total organic carbon, and organic matter compared to the control soil. Indeed, while the organic matter content was not sufficient $(2.48 \%)$ in the control soil, it had an acceptable value with $3.69 \%$ in the TWP. Carbon levels reflected this organic matter $(1.44 \%$ for control vs $2.14 \%$ for TWP) content because of the very close relationship between the two parameters. The enrichment of the soil in colloidal elements (humus and clay) and in magnesium can be a source of improvement of the texture and soil structure. The good level of CEC of the TWP confirmed enrichment in clay and organic matter, components with high exchange capacity. This physical and chemical contribution of the TWP made it to be an organo-mineral amendment of interest.

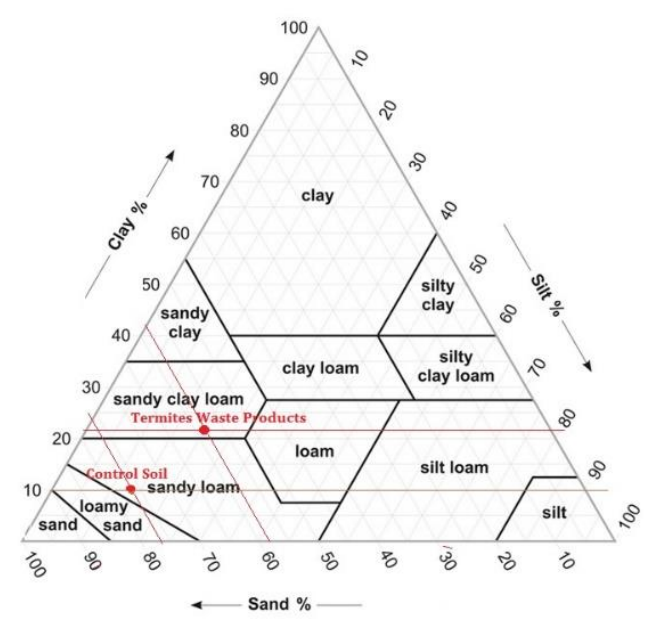

Fig. 3: Texture of the TWP according to the USDA Texture Chart.

These improvements could be of a certain beneficial to crops, especially since TWP did not significantly alter soil $\mathrm{pH}$. Indeed, $\mathrm{pH}$, an important parameter in soil dynamics, influences three important components of soil fertility: nutrient bioavailability, biological activity, and structural stability [31], [32].

The improvement of the fertility parameters justified the good behaviour of the plants on the soils that had received the TWP in amendment. The plots that received the TWP had a textural advantage by remaining in the same favourable $\mathrm{pH}$ zone for rice [33]. Soil organic matter is an important indicator of soil quality through its contribution to stability, soil water retention and as a substrate for microorganisms in the soil [34]. In addition, the nutrients availability was more favourable to production in the presence of termite amendment than without amendment. In fact, in agricultural practice, in order to obtain large yields, people fertilize their crops most commonly with mineral fertilizers containing nitrogen, phosphorus and potassium. Their efficiency depends on the soil physical properties [35]. TWP is a product with organic and mineral content that combine organic and mineral activities on soil. Its application improved soil physical and chemical properties that could modify nutrient availability positively. The physical action is essential for the sustainability in the fertility management. 
TABLE I: CHARACTERISTICS OF THE SOIL AND TWP

\begin{tabular}{lccccccccccc}
\hline \multicolumn{1}{c}{ Sample } & \multirow{2}{*}{$\mathrm{pH}$} & $\mathrm{C}$ & $\mathrm{N}$ & $\begin{array}{c}\mathrm{M} \\
\mathrm{O}\end{array}$ & $\begin{array}{c}\text { P.ass } \\
(\mathrm{ppm})\end{array}$ & $\begin{array}{c}\mathrm{CEC} \\
\mathrm{cmol} . \mathrm{kg}^{-1}\end{array}$ & $\mathrm{Ca}^{2+}$ & $\mathrm{Mg}^{2+}$ & $\mathrm{K}^{+}$ & $\mathrm{Na}^{+}$ & $\mathrm{V}$ \\
\hline $\begin{array}{l}\text { Control } \\
\text { soil }\end{array}$ & 6.8 & 1.4 & 0.13 & 2.4 & 63 & 9.3 & 25.8 & 23.7 & 1.1 & 1.1 & 51.6 \\
TWP & 6.2 & 2.1 & 0.19 & 3.6 & 83.7 & 13.2 & 21.2 & 16.7 & 6.5 & 2.2 & 46.5 \\
\hline
\end{tabular}

\section{B. Contribution of TWP to Rice Production}

The soil amendment with TWP significantly improved plant height $(\mathrm{P}=0.0014, \alpha=0.05)$ as depicted in Table II. $14.4 \%$ of TWP allowed the highest height $(105.22 \mathrm{~cm})$ of rice plant followed $7.2 \%$ TWP. The chemical fertilizer (NPK) application came in third position with $88.55 \mathrm{~cm}$ (Table II). Plants from non-fertilised soil had the lowest heights. The contribution of TWP significantly ( $\mathrm{P}=0.0053$, $\alpha=0.05$ ) improved foliar emission in rice. The number of leaves of the plants was increased with NPK, $14.4 \%$ and 1.8 $\%$ TWP. The T-test using the least significant difference (1sd $=0.62$ ) allowed fertility levels to be ranked in three (3) classes (Table II). The number of tillers increased with the TWP dose. It developed an average of 2.21 tillers per plant stand without TWP to reach 4.24 tillers per plant stand at $7.2 \%$ of TWP. The difference is significant $(\mathrm{P}=0.0075, \alpha=$ $0.05)$. Treats $\mathrm{T} 3(7.2 \%)$ and $\mathrm{T} 4(14.4 \%)$ showed good tillering in relation with biomass and plant height according to [16] justifying the good productivity for these doses in opposition with [37] who showed that yield is not directly correlated with vegetative development of the plant. Indeed, the yield in paddy is well correlated with tillering [16] on which depends the number of fertile tillers.

TABLE II: VARIATION OF SOME MORPHOLOGICAL PARAMETERS ACCORDING TO THE TREAT

\begin{tabular}{cccc}
\hline & $\begin{array}{c}\text { Plant height at } \\
\text { maturity }(\mathrm{cm})\end{array}$ & $\begin{array}{c}\text { Number of } \\
\text { leaves at 40 das }\end{array}$ & $\begin{array}{c}\text { Tillering at } \\
\text { maturity }\end{array}$ \\
\hline T0 (check) & $72.55^{\mathrm{d}}$ & $5.07^{\mathrm{c}}$ & $2.21^{\mathrm{c}}$ \\
T1 $(1.8 \%)$ & $83.72^{\mathrm{c}}$ & $6.28^{\mathrm{a}}$ & $2.68^{\mathrm{bc}}$ \\
T2 $(3.6 \%)$ & $89.29^{\mathrm{bc}}$ & $5.95^{\mathrm{ab}}$ & $2.86^{\mathrm{bc}}$ \\
T3 $(7.2 \%)$ & $95.25^{\mathrm{ba}}$ & $5.38^{\mathrm{bc}}$ & $3.33^{\mathrm{ab}}$ \\
T4 $(14.4 \%)$ & $105.22^{\mathrm{a}}$ & $6.21^{\mathrm{a}}$ & $4.24^{\mathrm{a}}$ \\
T5 (check) & $88.55^{\mathrm{bc}}$ & $6.21^{\mathrm{a}}$ & $2.49^{\mathrm{bc}}$ \\
CV (\%) & 6.88 & 5.78 & 17.08 \\
LSD & 11.15 & 0.62 & 0.92 \\
Pstar & $0.0014^{* *}$ & $0.0053^{* *}$ & $0.0075^{* *}$ \\
\hline
\end{tabular}

$\mathrm{CV}$ : Coefficient of variation; Averages followed by the same letter along the columns are not significantly different at the $5 \%$ threshold for the T-Test; 1sd: least significant difference; *: Significant at $0.05 ; * *$ : Highly significant difference at 0.01 ; das: day after sowing.

The effect of TWP on the agronomic parameters (height, number of leaves, tillering and biomass) of the rice showed its good fertility potential. Plots amended with TWP had better development in harmony with the results of [16] on rice and maize. Rice plants mobilize large quantities of nutrients with a special requirement for nitrogen, potassium and phosphorus plus calcium and magnesium [36]. The content of these elements in the soil determined the growth and the productivity of rice, thus explaining the good growth of rice on the T3 (7.2\% TWP) and T4 (14.4\% TWP) plots that have a good fertility level. The contribution of TWP had a significant effect on the plants biomass. This reflected the significant difference observed between the biomass for the different treats $(\mathrm{P}<0.01, \alpha=0.05)$. Thus, for fresh aerial biomass at maturity, the T-test classification using the least significant difference $(1 s d=10.89)$ allowed fertility levels to be ranked in two (2) classes where T4 (14.4\% TWP) was isolated with best amounts (Table III).

The large amount of vegetative and root biomass obtained in the T4 (14.4\% TWP) and the large size of the plants of the same treat compared to the others could be explained by a good availability of the nitrogen brought by the TWP.

TABLE III: AERIAL AND ROOT BIOMASS AT 139 DAYS AFTER SOWING EXPRESSED IN G PER PLANT

\begin{tabular}{ccccccc}
\hline & $\begin{array}{c}\text { Fresh } \\
\text { aerial } \\
\text { biomass }\end{array}$ & $\begin{array}{c}\text { Dry aerial } \\
\text { biomass }\end{array}$ & $\begin{array}{c}\text { Fresh } \\
\text { root } \\
\text { biomass }\end{array}$ & $\begin{array}{c}\text { Dry root } \\
\text { biomass }\end{array}$ & $\begin{array}{c}\text { Fresh } \\
\text { biomass of } \\
\text { the whole } \\
\text { plant }\end{array}$ & $\begin{array}{c}\text { Dry } \\
\text { biomass } \\
\text { of the } \\
\text { whole } \\
\text { plant }\end{array}$ \\
\hline T0 (Check) & $15.28^{\mathrm{b}}$ & $6.01^{\mathrm{b}}$ & $5.42^{\mathrm{c}}$ & $2.42^{\mathrm{c}}$ & $20.71^{\mathrm{b}}$ & $8.43^{\mathrm{b}}$ \\
T1 $(0.9 \%)$ & $17.05^{\mathrm{b}}$ & $7.02^{\mathrm{b}}$ & $7.76 \mathrm{~b}^{\mathrm{c}}$ & $3.47^{\mathrm{bc}}$ & $24.82^{\mathrm{b}}$ & $10.50^{\mathrm{b}}$ \\
T2 $(1.8 \%)$ & $17.17^{\mathrm{b}}$ & $6.95^{\mathrm{b}}$ & $6.44 \mathrm{~b}^{\mathrm{c}}$ & $2.90^{\mathrm{bc}}$ & $23.62^{\mathrm{b}}$ & $9.85^{\mathrm{b}}$ \\
T3 $(3.6 \%)$ & $18.52^{\mathrm{b}}$ & $7.32^{\mathrm{b}}$ & $7.26 \mathrm{~b}^{\mathrm{c}}$ & $3.24^{\mathrm{bc}}$ & $25.78^{\mathrm{b}}$ & $10.56^{\mathrm{b}}$ \\
T4 $(7.2 \%)$ & $39.36^{\mathrm{a}}$ & $16.06^{\mathrm{a}}$ & $13.76^{\mathrm{a}}$ & $6.17^{\mathrm{a}}$ & $53.13^{\mathrm{a}}$ & $22.24^{\mathrm{a}}$ \\
T5 (check) & $19.24^{\mathrm{b}}$ & $6.38^{\mathrm{b}}$ & $9.94^{\mathrm{b}}$ & $4.44^{\mathrm{b}}$ & $29.18^{\mathrm{b}}$ & $12.83^{\mathrm{b}}$ \\
CV $(\%)$ & 28.37 & 26.20 & 22.96 & 23.20 & 24.98 & 24.19 \\
lsd & 10.89 & 4.11 & 3.52 & 1.59 & 13.43 & 5.46 \\
Pstar & $0.005^{* *}$ & $0.002^{* *}$ & $0.004^{* *}$ & $0.004^{* *}$ & $0.003^{* *}$ & $0.002^{* *}$ \\
\hline CV: Cocffic
\end{tabular}

$\mathrm{CV}$ : Coefficient of variation; the averages followed by the same letter along the columns are not significantly different at the $5 \%$ threshold for the T-test. 1sd: least significant difference; *: Significant at 0.05 ; **: Highly significant difference at 0.01 .

The paddy yield showed a highly significant difference between soil fertility ( $\mathrm{P}=0.0002, \alpha=0.05$ ) (Table IV). The T-test using the least significant difference $(1 \mathrm{sd}=511.68)$ allowed fertility levels to be ranked in four (4) classes including one intermediate.

TABLE IV: YIELD OF RICE UNDER TWP FERTILIZATION IN KG.HA ${ }^{-1}$

\begin{tabular}{cccc}
\hline & $\begin{array}{c}\text { Grain Yield } \\
\left(\mathrm{kg} / \mathrm{ha}^{-1}\right)\end{array}$ & $\begin{array}{c}\text { Efficacy1 to no- } \\
\text { fertilised soil }(\%)\end{array}$ & $\begin{array}{c}\text { Efficacy to chemical- } \\
\text { fertilised soil (\%)* }\end{array}$ \\
\hline T0 (Check) & $771,6 \mathrm{~d}$ & 0,00 & $-46,42$ \\
T1 $(1.8 \%)$ & $981,1 \mathrm{~cd}$ & 27,15 & $-31,87$ \\
T2 $(3.6 \%)$ & $1207,30 \mathrm{~cd}$ & 56,47 & $-16,17$ \\
T3 $(7.2 \%)$ & $2484,30 \mathrm{a}$ & 221,97 & 72,51 \\
T4 $(14.4 \%)$ & $1872,40 \mathrm{~b}$ & 142,66 & 30,02 \\
T5 (Check) & $1440,10 \mathrm{bc}$ & 86,64 & 0,00 \\
\hline
\end{tabular}

The averages followed by the same letter along the columns are not significantly different at the 5\% threshold for the T-Test; LSD $=511.68$ $\mathrm{kg} \cdot \mathrm{ha}^{-1} *$ : The sign (-) corresponds to a yield gap compare to the chemicalfertilized control treatment (T5).

Termites waste products progressively increased rice yield (Fig. 4) from $771.6 \mathrm{~kg} \cdot \mathrm{ha}^{-1}$ without fertilizer to $2484.3 \mathrm{~kg} \cdot \mathrm{ha}^{-1}$ with the dose T3 (7.2\% of TWP) considered as optimum yield. Beyond this dose $(7.2 \%)$, the yield decreased considerably to reach $1872.4 \mathrm{~kg} \cdot \mathrm{ha}^{-1}$ at T4 dose (14.4\%) inducing $30.02 \%$ yield loss compared to that received from NPK treatment. Yield obtained with the mineral fertilizer gave a loss of $72 \%$ productivity compared to the optimum considered at $2484.3 \mathrm{~kg}$.ha ${ }^{-1}$ obtained with 7.2 $\%$ TWP application (Table IV). The curve of Fig. 4 highlighted the law of less-than-proportional surpluses in rice yield submitted to termite wastes products as amendment. 


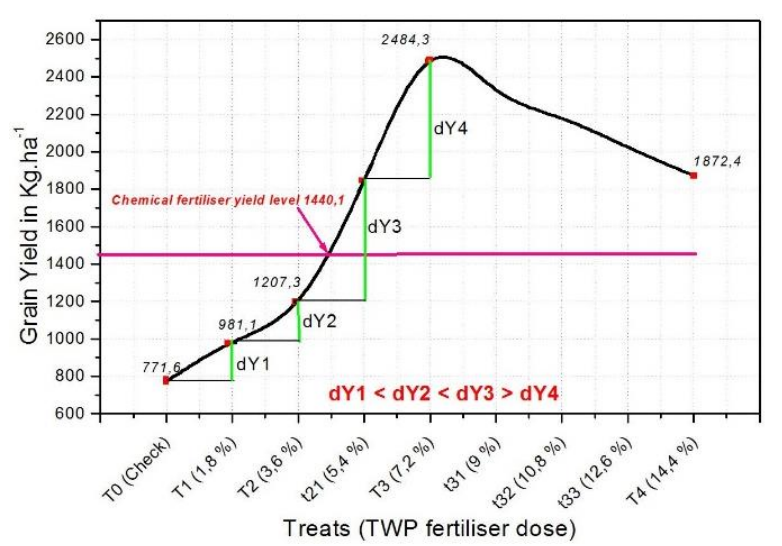

Fig. 4: Evolution of rice yield as a function of TWP dose.

In fact, the addition of the same TWP dose improved yield with increasing increment up to the optimum yield than, that increment decreased. T3 (7.2\% TWP) yielded more than T4 (14.4\% TWP) despite low tillering, as for [38], low fertility levels can produce better yield with less tillers. The superiority of the yield obtained with $7.2 \%$ TWP compared to $14,4 \%$ TWP led to the hypothesis of the existence of a depressive effect of the TWP on the yield at $14.4 \%$. The yield deficit observed with the highest dose of TWP while the height and the number of tillers increased, reflected a luxury consumption justifying the law of less-thanproportional surpluses in rice production under termite wastes products fertilisation. In fact, the addition of $1.8 \%$ produced yield gain up to the optimum dose then, it induced yield losses. The yield level with $14.4 \%$ TWP could also been explained by a disruption of grain filling phase by water deficit in December, corresponding to the end of the rainy season in accordance with [39]-[42]. In fact, high doses of fertilizers generate high water requirements that the plant did not cover in conditions of water stress, leading to a drastic reduction in grain yield [43]. Indeed, TWP is more clayey than control soil and, increasing its dose, increased soil clay level. In clayey conditions, drought effects are important on crops. This phenomenon made it possible to determine the optimal TWP dose at $7.2 \%$ (T3), applicable for rainfed rice cultivation under Ivorian central west soil conditions. A TWP recommendable dose should be around $7.2 \%$. African farmers had good practices by using termite waste products to fertilise their fields. They had certainly profit in practising so since, TWP application induced higher yield than nonfertilised plot even, more than plots fertilised with common $\mathrm{NPK}+$ Urea combined fertilisation. Indeed, the Yield gap is positive and varied from $30 \%$ to $72 \%$ when compared to mineral fertiliser similar to [44]. The TWP showed good yield potential in regards with its mineral and organic content. The CEC was at good level as well as major cations $\left(\mathrm{Ca}^{2+}, \mathrm{Mg}^{2+}\right)$ contributing for $21.2 \%$ and $16.7 \%$ to soil saturation. The soil saturation had been improved in relation with textural and organic improvement, thus, Clay and organic matter are responsible for soil mineral adsorption. Soil pH had also been improved increasing plants nutrition conditions. Those good properties allowed TWP fertilised plots to yield 27.1 to $221.9 \%$ more than non-fertilised plots from $1.8 \%$ TWP to $7.2 \%$ TWP application. Used at $3.6 \%$, TWP provided $56.5 \%$ efficacy but stayed not enough to overcome mineral fertiliser. TWP applied $(1.8 \%-7.2 \%)$ had been 0.27 to 2.21 times more efficacy than non-fertilised plot and 0.3 to 0.72 times efficacy than mineral fertilisation. The low TWP applications (1.8 to $3.6 \%$ ) produced less than mineral fertiliser.

\section{CONCLUSION}

The study of the physicochemical characteristics of termite wastes products showed that this product is an organo-mineral amendment of interest. Its' application contributed to the improvement of height, tillers production, total biomass content and especially it improved the yield of paddy from $771.6 \mathrm{~kg} \cdot \mathrm{ha}^{-1}$ (without fertilizer) to $2484.3 \mathrm{~kg} \cdot \mathrm{ha}^{-1}(7.2 \%)$ better than NPK application $1440.1 \mathrm{~kg} \cdot \mathrm{ha}^{-1}$. The TWP efficacy had varied between 27.1 and $221.9 \%$ and from 30 to $72 \%$ in comparison with nonfertilised and mineral fertilisation respectively. Yield improvement is the consequence of soil texture and chemical properties improvement.

All these results showed that the termite waste product can contribute to build a sustainable solution to soil fertility management and could be valued as an effective soil organic amendment to increase rice productivity. In addition, it is a simple technique that is within the reach of the farmers and it allows to reduce farmers' expenses for agricultural inputs as far as chemical fertilisers are considered. In addition, it has the advantage of promoting poultry farming by making available food for these animals. However, it would be interesting to determine the conditions of a large-scale production to facilitate its extension. The research is going on and massive production methods are in test in respect of the termites and their environment.

\section{APPENDIX}

This appendix provides a graphical summary of the TWP production process and the application made in rice field.

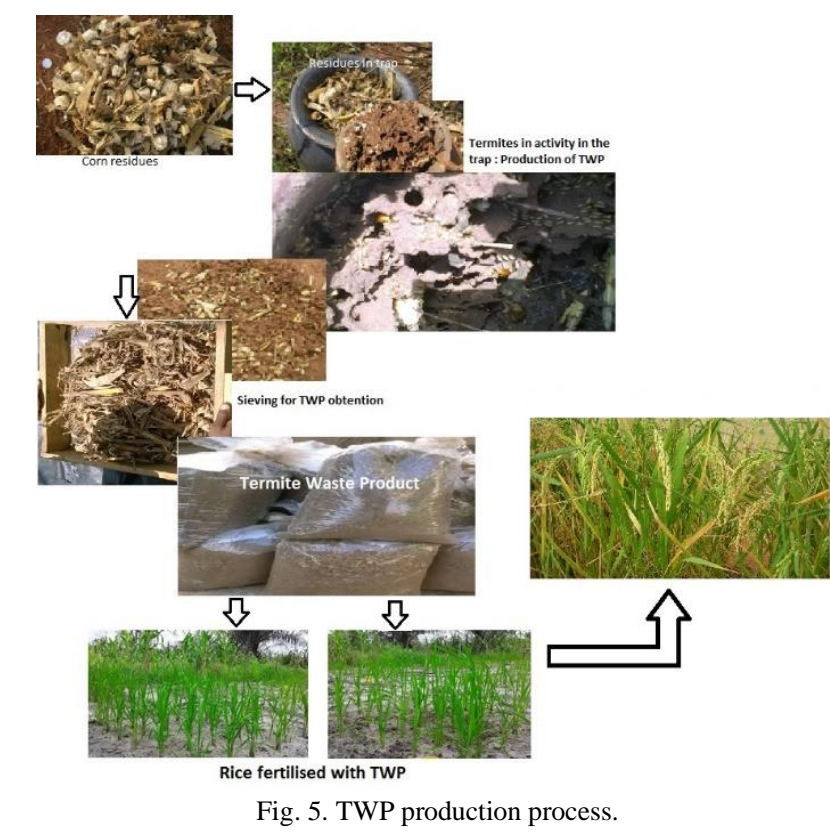




\section{ACKNOWLEDGMENT}

Authors thank Jean Lorougnon Guede University authorities for all support for this study that valorised farmers knowledge and each farmer who contribute to the work.

\section{REFERENCES}

[1] P. Krishnan, B. Ramakrishnan, K.R. Reddy and V.R. Reddy, "Hightemperature effects on rice growth, yield, and grain quality". Advances in Agronomy, 111: 87-206, 2011.

[2] FAO, Système amélioré de riziculture pluvial, 2013, 121p.

[3] FAO, Production et superficie mondiales de riz Paddy. Résumé du suivi du marché du riz, relevé d'avril, 2012, 5p.

[4] Balasubramanian V., Sié M., Hijmans R.J. and Otsuka K.: Increasing rice production in sub-saharan Africa: Challenges and opportunities. Advances in Agronomy, 94 : 55-133, 2007.

[5] F. Bahan, F. Kassin, B. Kone, J.M. Johnson, H. Gbakatchetche, A. Bouët, Z. Keli, A. Yao-Kouame et M Camara, «Impact de la riziculture traditionnelle sur la fertilité du sol: Incidence de l'association riz (Oryza sativa L.) - maïs (Zea mays L.) sur quelques propriétés physiques d'un ferralsol dans le Centre Ouest de la Côte d'Ivoire». Asian journal of science and technology vol 7 n 3: 25882595, 2016.

[6] Africa Rice, « Rice production trends », Cotonou, Bénin, 2008, 86p.

[7] CNRA, 'Le paillage par le pois d'angole pour améliorer le rendement du riz pluvial en Côte d'Ivoire', 2011, www.cnra.ci. Consulté le $10 / 12 / 18$.

[8] J. Gigou, ' 'L'azote dans les systèmes de culture du nord et du centre de la Côte d'Ivoire''. In: Munlongoy K, Gueye M et Spencer DSC (Eds). Biological nitrogen fixation and sustainability of tropical agriculture. John Wiley and Sons, Chichester, 1992, pp. 337-394.

[9] E. Roose, J. Albergel, G. De Noni, M. Sabir et A. Laouina ''Efficacité de la GCES en milieu semi-aride', AUF, EAC et IRD Editeurs, Paris. 2008, 425p.

[10] J. M. Harmand et P. Ballé, 'La jachère agroforestière (arborée et arbustive) en Afrique tropicale'. In : La jachère en Afrique tropicale: De la jachère naturelle à la jachère améliorée. Le point des connaissances, Paris, France, John Libbey, 2001 vol. 2 pp. 265-292.

[11] F Ganry, Z. J. L. Sanogo, J. Gigou et R. Olivier, 'Intensification du système cotonnier-sorgho au Mali-sud fondée sur le fumier et la gestion optimale de la fertilisation', In : La jachère en Afrique tropicale : Rôles, aménagements, alternatives. Actes du séminaire International, Dakar, 13-16 avr. 1999, vol. I, John Libbey, Paris, 2000, 804p.

[12] A. Kouadio « Arrières effets du niébé (Vigna unguiculata et du soja (Glycine max) sur les céréales : cas du riz pluvial et du maïs », Mémoire de BTS Agricole. INFPA, Abengourou, Côte d'Ivoire, 2003, 21p.

[13] F. Lompo, « Effets induits des modes de gestion de la fertilité sur les états du phosphore et la solubilisation des phosphates naturels dans deux sols acides du Burkina-Faso ". Thèse de Doctorat d'Etat ès Sciences Naturelles. Université de Cocody, Côte d'Ivoire, 2008, $214 \mathrm{p}$.

[14] ONDR, (2015). Production du riz en Côte d'Ivoire de 2010 à 2015. Ministère de l'Agriculture, http://www.ondr.ci/statistique_production.php, Consulté le 31/08/ 2018.

[15] Bationo A. et Somda Z, (1994). Gestion de la fertilité des sols. In : W. B. Hoognoed, M. C. Klaij (Eds.). Le travail du sol pour une agriculture durable, Cours de formation, 4 - 13 juillet 1994. FAO, W.B. Hoogmoed M.C. Klaij.Niamey, Niger, http://www.fao.org/docrep/W7304F/W7304F00.htm consulté le 02/08/18.

[16] J. Boga, P. Kouassi, A. Yapi, A. Tahiri et Y. Tano « Influence de matériaux termitiques sur quelques paramètres agronomiques de deux cultures vivrières en milieu de savane de côte d'lvoire: Effects of termites mound material on the growth of food crops in the savannaa areas of lamto and booro-borotou ». Agronomie Africaine, 2000, vol 12 pp. $1-10$.

[17] B. Dabin, N. Leneuf et G. Riou « Carte pédologique de la Côte d'Ivoire au 1/2.000.000. Notice explicative ». ORSTOM, 1960, 39 p.

[18] Y.T. Brou, «Climat, mutations socio-économiques et paysages en Côte d'Ivoire ». Mémoire de synthèse des activités scientifiques. Habilitation à Diriger des Recherches, Université des Sciences et Technologies de Lille, France, 2005, 2p.
[19] M. Eldin, «Le climat», In: Le Milieu Naturel de la Côte d'Ivoire, 1971, pp. 73-108.

[20] L. Becker et R. Diallo, «Caractérisation et classification des écosystèmes rizicoles de la Côte d'Ivoire. ADRAO, Bouaké, Côte d'Ivoire ». 1992, 301p.

[21] G. Bi T. Jérémie, C. Maméri, N. Mako, K. Z. Jules, « Bien fertiliser le riz pluvial en Côte d'Ivoire, Fiche technique », Comité de validation : O. Tahouo, J.Z. Kéli, G.B. Déa, M.B. Béninga. Direction des programmes de recherche et de l'appui au développement Direction des innovations et des systèmes d'information, 2010.

[22] E. Van Ranst, M. Verloo, A. Demeyer and J.M. Pauwels, "Manual for the Soil Chemistry and Fertility Laboratory-Analytical Methods for Soils and Plants, Equipment, and Management of Consumables". NUGI 835, Ghent, Belgium (ISBN 90-76603-01-4), 1999, 243 pp.

[23] A. Walkley and C. A. Black "An examination of the Degtjareff method for determining soil organic matter and a proposal modification of the chromic acid titration method". Soil Science, 1934 vol 37 pp. 29-38.

[24] S.R. Olsen, C.V. Cole, F.S. Watanabe, and L.A. Dean, "Estimation of available phosphorous in soils by extraction with sodium bicarbonate". U.S. Department of Agriculture, Washington DC, 1954, vol 939 pp. 1-19.

[25] C.A. Bower, R.F. Reitemeier and M. Fireman, « Exchangeable cation analysis of saline and alkali soils », Soil Science 1952 vol 73 pp. 251261.

[26] J. Pétard «Les méthodes d'analyse employées au Laboratoire du Centre ORSTOM de Nouméa (Nouvelle Calédonie) », Notes tech., Lab. Commun Anal. 1991 vol. 4, 24p.

[27] A. Duboisset, « L'importance agricole des termitières épigées dans le nord du Cameroun : l'exemple des nids de Macrotermes subhyalinus et d'Odontotermes magdalenae ». Thèse en Sciences et techniques de l'environnement. Paris Université de Paris-Val-de-Marne, 2003, $479 \mathrm{p}$.

[28] P. Jouquet, S. Traoré, C. Choosai, C. Hartmann and D. Bignell, "Influence of termites on ecosystem functioning. Ecosystem services provided by termites". European Journal of Soil Biology, $2011 \mathrm{vol}$. $47 \mathrm{n}^{\circ} 4$, pp. $215-222$.

[29] T.G. Wood, R.A. Johnson and J.M. Anderson, "Modification of soils in Nigerian savanna by soil feeding Cubitermes (Isoptera, Termitidae)". Soil Biol. and Bioch, 1983 vol 15 pp. 575-579.

[30] Y. Tano, «Les termitières épigées d'un bassin versant en savane soudanienne : répartition et dynamique des nids, rôle sur les sols et la végétation ». Thèse d'Etat ès Sciences, Université Nationale de Côte d'Ivoire, 1993, $250 \mathrm{p}$.

[31] D. Baize, «Guide des analyses en pédologie: choix, expression, présentation, interprétation » 2e éd, INRA-paris 2000, 255 p.

[32] E. Dinon et A. Gerstmans, « L'Influence du pH sur l'assimilation des éléments nutritifs du sol par les plantes et sur la variété des plantes » Université de Liège. Printemps des Sciences, 2008, 4p. www2.ulg.ac.be/sciences/printemps/pedagogique/l151.pdf. Accédé le 15 décembre 2017.

[33] S. Zingore, L. Wairegi et K. M. Ndiaye, « Guide pour la gestion des systèmes de culture de riz ». Consortium Africain pour la Santé des Sols, Nairobi, 2014, 60p.

[34] T. Drouet: Pédologie. BING-F- 302, 2010,137p

[35] C.A. Elalaoui, «Fertilisation Minérale des Cultures: les éléments fertilisants majeurs (Azote, Potassium, Phosphore)». Bulletin mensuel d'information et de liaison du PNTTA, 2007, $\mathrm{n}^{\circ} 155,4 \mathrm{p}$.

[36] M. Jacquot et B. Courtois, «Le riz pluvial, Le technicien d'agriculture tropicale ». Edition : Maisonneuve Larose, Paris, 1983, $134 \mathrm{p}$

[37] G. R. Guéi, K. A. Sanni, F. S. Abamu and I. Fawolé, «Genetic diversity of rice (Oryza sativa L). landraces from Côte d' Ivoire ", Agronomie Africaine, 2005, vol 5 pp. 17 - 28

[38] B. Koné, J.B. Ettien, G. Amadji et S. Diatta: « Caractérisation de la tolérance de NERICA à la sécheresse de mi-saison en riziculture pluviale ». African Crop Science Journal, 2008 vol 16 n² 2, pp. 133145.

[39] La fertilisation minérale du riz. Memento Technique de Riziculture, M. Lacharme, 2001, 17p

[40] Guide d'identification des contraintes de terrain à la reproduction du riz. Commission international du riz, FAO, Rome, R.C. Chaudhary, J.S. Nanda et D.V. Tran, 2003, 79 p

[41] M. Dicko « Analyse du fonctionnement d'une parcelle de riz irrigué sur sol alcalin. Application à la gestion intégrée de la fertilisation azotée et du calendrier cultural dans le delta intérieur du fleuve Niger (Niger) ». Thèse de Doctorat de l'ENSAM. Mali. 2005, $153 \mathrm{p}$

[42] Guide pratique de la culture des NERICA de plateau, ADRAO, I Akintayo., B. Cissé et L.D. Zadji, 2008, 29p. 
[43] R. Lafitte, "Relationship between leaf relative water content during reproductive", 2002.

[44] D. Soro, D. Dao, R. J. Carsky, R. Asiedu, A. Assa et O. Girardin, «Amélioration de la production de l'igname à travers la fertilisation minérale en zone de savane de Côte d'Ivoire », Agronomie Africaine, 2001, vol 1, Numéro spécial, pp 9 - 14.

[45] W.F. Hillebrand, G.E.F. Lundell, H.A. Bright and, J.I. Hoffman, "Applied inorganic analysis", 2nd ed. John Wiled and Sons, Inc., New York, USA, 1953, 1034 p.

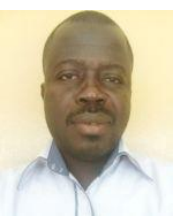

Soro Dogniméton was born in Fangassokaha (Sinématiali, Côte d'Ivoire). After primary snd grammar school in the north, he reached University where he studied natural sciences. After the Master in Plant and environnement protection, he got the DEA and the doctorat at Cocody university.

$\mathrm{He}$ studied soil sciences in relation with croops productivity and had several fellowship experiences in Ivory coast and Nigeria. He is actually, lecturer at Jean Lorougnon Guede University where he teaches soil sciences and have research activities on soil fertility and productivity. Dr Dogniméton is member of the Ivoirian Soil Science Association. 